\title{
Curriculum Management in Early Childhood Education
}

\author{
Frinza \\ Universitas PGRI Palembang \\ e-mail: faadhilah@gmail.com \\ Muhammad Kristiawan \\ Universitas Bengkulu \\ e-mail: muhammadkristiawan@unib.ac.id

\section{Houtman} \\ Universitas Muhammadiyah Palembang \\ e-mail: houtman03@yahoo.co.id
}

Article History: Received on 15 February 2021, Revised on 20 February 2021,

Published on 21 February 2021

\begin{abstract}
Potential Early childhood can be developed through proper planning, implementation and evaluation of the learning curriculum. This paper is a qualitative study which carried out indepth observations at TKIT Islahul Ummah Prabumulih City. The results obtained indicate that PAUD learning activities begin with 1) curriculum planning starting from meetings attended by all educators, making annual and semester program curriculum plans as well as the design of weekly activities and the design of daily activities; 2) curriculum implementation has used in door activity and out door activity; 3) curriculum evaluation is carried out periodically and has been set a time, every once a month parents of students are invited to discuss and talk about learning that has been done one month before. This paper provides new insight for implementation of curriculum management for early childhood education should refer to the national curriculum with additional Islamic religious material where we could have character building for our student.
\end{abstract}

Keywords: Management, Curriculum, Early Childhood Education

\section{A. Introduction}

Early age is the basic foundation of the process of human growth and development, with a characteristic known as the golden age (Ulfa \& Munastiwi: 2020). Early childhood education is a fundamental educational vehicle as a coaching effort aimed at children in providing a basic framework for the formation and development of the basics of knowledge, attitudes and skills by providing educational stimuli so that children have readiness to enter further education (Afiif et al, 2019; Mukminin \& Cahyani, 2017).

Minister of Education and Culture Mr. Nadiem Makarim at the Indonesia PAUD Activist Creativity Event in Jakarta on December 13, 2019 said that the most important education was PAUD education. In PAUD institutions, all teacher creativity and competence cannot be hidden. Elementary, junior high, high school teachers and even lecturers should visit PAUD frequently to see the complexity of education at this level (Balipost.com, 13 December 2019). 
Volume 1 (3) 2020

E-ISSN: 2723-6919 P-ISSN:2746-0827

President Jokowi stressed the importance of education in early childhood for the development of Indonesian children. The Head of State stated and acknowledged the important role of PAUD teachers who participated in educating the lives of the nation's children. This was conveyed during the closing ceremony of the grand development of early childhood education (PAUD) teachers throughout DKI Jakarta Province at the Islamic Center in Jakarta. Intelligence and character are built at the golden age of 1 year to 12 years. PAUD teachers are in a very important role in determining the direction of the life of the nation and state in the future, explained President Jokowi in a press release. Because children's intelligence will produce a balance between character and good character towards the glory of Indonesia Emas in 2045 (Bisnis.com, 20 September 2017).

According to Masitoh, et al (2014), early childhood education emphasizes the growth of children including motor skills, emotional intelligence, and spiritual intelligence in accordance with the stage of child development. If PAUD management is good, the learning outcomes received by students will also be good. Children will not experience pressure when they are still in PAUD, especially later when children have occupied the elementary school (SD). The Director General of Early Childhood Education at the Ministry of Education and Culture (Dirjen PAUD Kemendikbud) Mr. Harris Iskandar revealed that early childhood education (PAUD) is a benchmark for one's education. If the PAUD is good, then the child will not drop out of elementary, junior high, until high school, he said on the sidelines of the National Conference on Education and Culture or RNPK 2019 at the Education and Training Center of the Ministry of Education and Culture, Serua, Bojongsari, Depok City, West Java, Tuesday, 12 February 2019 (Liputan6.com, February 13 2019).

Educational management is a series of collaborative business management activities in an educational organization, to achieve educational goals, by utilizing resources and carrying out management functions so that effective and efficient goals are achieved. According to Irawan (2020) and Suharni (2019) the success or failure of the education process is very dependent on the management of the curriculum, if one of the curriculum components is not implemented properly, it will result in the curriculum system running less optimally. In realizing PAUD to develop the potential of early childhood, planning, organizing, actuating and controlling are abbreviated as POAC. Without POAC, the learning process cannot run well (Rozalena and Kristiawan, 2017).

Mr. Edi Sumartono as Dapodik Operations Staff in the Education and Culture Office of Prabumulih City, and also confirmed by Mr. Darmin, S.Pd., M.Sc. as the KABID for the Development of Paud and PNF in Prabumulih, stated that from Dapodik data in the Prabumulih City Education Office that the Islahul Ummah Islamic Kindergarten (TKIT) is one kindergarten that has more students than other kindergartens. TKIT Islahul Ummah is an educational institution that carries out learning in early childhood that is based on integrated Islam. Implementation and implementation of the curriculum, this school applies a balance between IQ, EQ, and also SQ of students (the results of the initial interview with the head of TKIT Islahul Umi Wita Anjasmara, S.Pd.AUD, March 30, 2019). Based on the results of the initial interview with TKIT teacher Islahul Ummah Umi Septi Nurul Hapsari, S.E. on March 30, 2019, in addition to activities carried out inside the classroom (indoor), learning was also carried out outside the classroom (outdoor) with the concept of play.

The author chose PAUD TKIT Islahul Ummah as a research subject for very clear reasons. First, TKIT Islahul Ummah has a strong commitment in the implementation of education, 
Volume 1 (3) 2020

E-ISSN: 2723-6919 P-ISSN:2746-0827

evidenced by the vision of PAUD that is the realization of children who are smart, healthy, and of good character. Second, TKIT Islahul Ummah applies an integrated curriculum between the Ministry of Religion curriculum, and the Ministry of National Education Curriculum which is adjusted to the demands of the need to be able to compete in the City of Prabumulih. Third, there are more students compared to other kindergartens, this is evidenced from Dapodik Data from the Education and Culture Office of Prabumulih City. Fourth, TKIT Islahul Ummah is a kindergarten under the auspices of the largest Foundation in the City of Prabumulih. For these four reasons researchers are interested in conducting curriculum management research at PAUD at TKIT Islahul Ummah Prabumulih City which is focused on PAUD curriculum management which consists of 1) curriculum planning; 2) curriculum implementation; and 3) curriculum evaluation.

\section{B. Methods}

This research was a qualitative research. The subject in this study was PAUD management at TKIT Islahul Ummah, Prabumulih City. The object of this research is TKIT Islahul Ummah. This research was focused on answering about PAUD management which consists of 1) curriculum planning; 2) curriculum implementation; and 3) curriculum evaluation. This study used data collection techniques in the form of participant observation, in-dept interviews, and documentation. The data were analyzed qualitatively using Miles and Huberman's theory.

\section{Results and Discussion}

\section{Curriculum Planning}

The curriculum planning carried out at TKIT Islahul Ummah through two processes. First, the curriculum planning discussion meeting attended by all TKIT Islahul Ummah educators. Second is the making of an annual and semester program curriculum plan as well as a weekly activity plan and daily activity plan.

The main scope of the curriculum is to develop learning programs that are in accordance with the vision and mission of the foundation. Its existence is directly related to the teaching and learning process in the classroom, so in preparing the RKM and RKH in managing the curriculum it requires professional management staff. The Daily Activity Plan prepared by TKIT Islahul Ummah teacher contains activities, time allocation, abilities and evaluation. Daily Activity Plans for activities including initial activities, core activities, time allocation, integration of themes with activities, evaluations and conclusions. The steps taken in implementing the Daily Activity Plan are 1) the teacher studies and writes in the class administration's Daily Activity Plan book; 2) make a Student Worksheet (LKS) integrated with the theme; 3) determine the method that is tailored to the ability of students.

Based on observations and documentation, TKIT Islahul Ummah in planning the Weekly Activity Plan has integrated the ability to be achieved with other abilities, especially religious. Before planning activities, weekly meetings are held together by the teacher. This learning activity is gathered in accordance with the theme which takes place in one week. With the theme makes it easier to find activities related to student development.

The TKIT Islahul Ummah semester program contains elements of Basic Competence (KD), themes, sub themes, and time allocation. KD determination includes all aspects of the 
Volume 1 (3) 2020

E-ISSN: 2723-6919 P-ISSN:2746-0827

development of religious and moral values (nam), motor (motr), cognitive (kog), socialemotional (social), language (bah), and art. KD writing can be written in full or can be written only the code. Themes can be developed into sub-themes or up to sub-themes. Time allocation is adjusted to the needs of each theme/sub-theme/sub-theme. KD can be repeated in each theme/sub theme/sub-sub theme.

An annual program has been made jointly, namely the school principal and TKIT Islahul Ummah teachers who consider the situation of students for the next year. From the annual activity plan that has been designed by TKIT Islahul Ummah then becomes a reference in making the semester activity plan. The design of the semester activity is a plan of activities that will be taken during one semester, where it is stated in the Weekly Activity Plan and Daily Activity Plan that has been made by the teacher. This can be seen from the calculation of the time allocation related to the existence of active days during a semester which is well programmed.

\section{Implementation}

The curriculum implementation at TKIT Islahul Ummah already uses in door activity and out door activity. The methods used include the demonstration method, the storytelling method, the question and answer method, the field trip method and the assignment method. The concept of schools in TKIT Islahul Ummah is Islamic-oriented. TKIT Islahul Ummah in the development of Islamic religious education through fostering morals and creeds that are integrated in all learning activities as well as in moral behavior education towards teachers, friends, parents and people in the school environment and at home.

\section{Learning Methods}

TKIT Islahul Ummah in learning activities also applies the center method. Some of the centers in learning at TKIT Islahul Ummah are 1) centers of natural materials; 2) beam centers; 3) art centers; 4) preparatory centers; 5) the role playing center. The center of natural materials is synonymous with knowledge of science, mathematics, and art. Natural center materials come from nature, such as soil, water, sand, rocks, leaves and seeds. At the center of natural materials, children have the opportunity to use play materials in various ways according to their minds with different results for each child. The materials and equipment used must be safe, clean and free of toxic materials or small animals that are harmful to children.

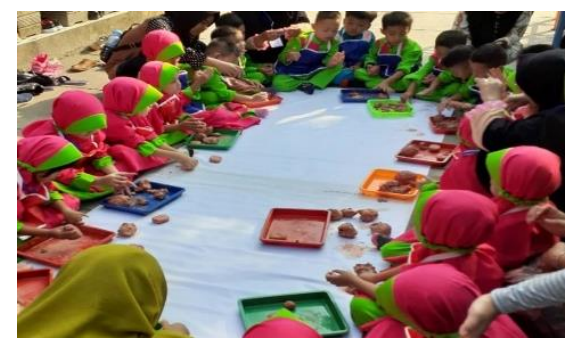

\section{Figure 1. Activities of Natural Centers Using Natural Materials, Namely Soil}

The beam center makes children think and play about the concept of shape, size, and linkage of shapes. Beams that are used and arranged make children can develop thinking skills about simple mathematical logic, thinking ability, and find solutions to problems. Tools that can be 
Volume 1 (3) 2020

E-ISSN: 2723-6919 P-ISSN:2746-0827

used in beam centers, for example 1) beams of various shapes and sizes; 2) accessories blocks for role playing; 3 ) legos of various shapes; 4) paper and stationery.

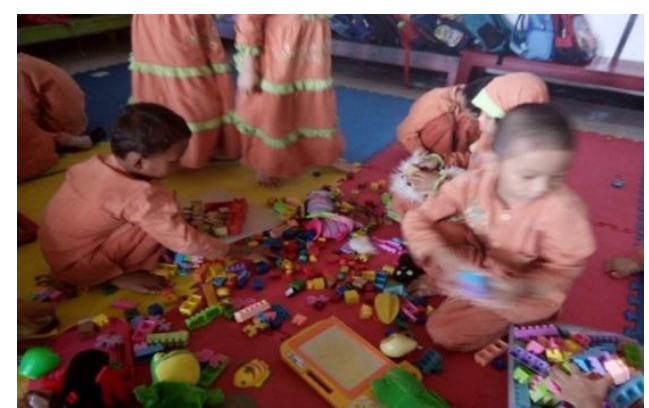

Figure 2. Center Activities by Playing Lego

The center of art that is developed depends on the ability of learning in PAUD units. Art centers can be in the form of music, dance, sculpture or craft. The arts center combines fine motor skills, tone, harmony of movement, and other social and emotional aspects of the child.

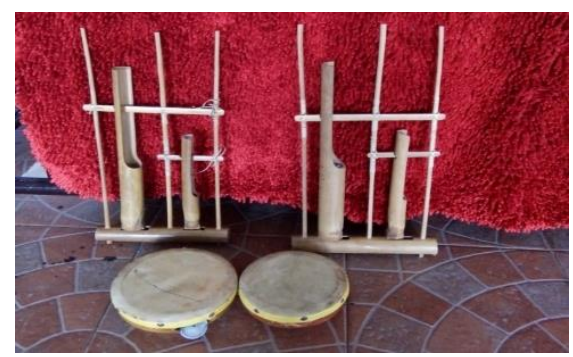

Figure 3. TKIT Islahul Ummah Art Center

Preparatory centers are more focused on the introduction of early literacy in children, the use of books, stationery can also be done in all centers, but in the preparation centers more enriched types of play activities. For children in group B or big zero who will soon enter elementary school, the frequency of playing at the center of preparation is more. Preparatory activities can also be strengthened in the afternoon journal.

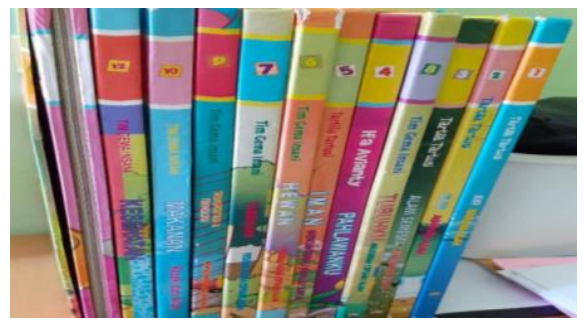

Figure 4. Muslim Children's Encyclopedia Book Used at TKIT Islahul Ummah

The role playing center develops language skills, emotional maturity, and develops the ability to recognize the social environment, by using game tools. Tools and materials and materials that can be used include tools for housing, markets, various types of professions such as doctors, carpenters, fishing activities, salons, and others. 


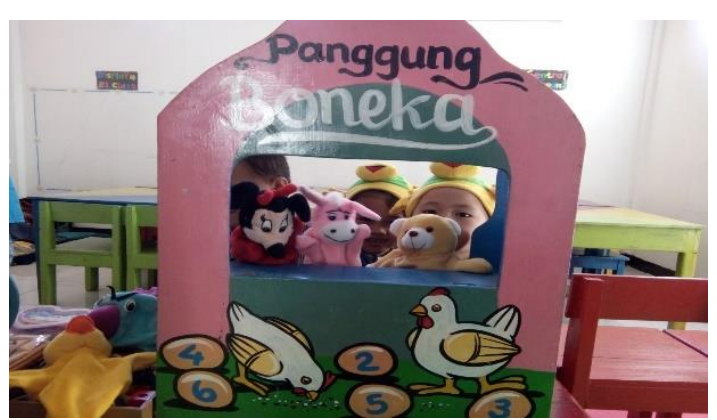

Figure 5. Activity Center Playing Role

Learning Media

Some of the uses of several learning media used at TKIT Islahul Ummah and the things that must be considered in their use are as follows. 1) Print media, the absolute book used by teachers as learning resources. Some criteria that should be used as a basis for consideration in using books are content criteria which include whether the contents of this book are relevant to the applicable curriculum / program, the order of the contents of the book, the contents and topics presented are easily understood by children, the ability of authors and publishers, etc. . 2) Actual objects, in line with early childhood learning, teachers can use actual objects as learning media. The use of actual objects as when the teacher explains the plants such as flowers the teacher must be able to use appropriately and utilize these objects so that a child's senses are stimulated properly for example the child can observe the real flower, smell the fragrant flowers, touch the crown, leaves and stems interest, thus children understand better through real experiences and are more pleasant. 3) Used goods, teacher's creativity in using used goods into learning media can help the learning process. For example bottles of used beverage cans can be packaged into sound cans with the help of pebbles to practice the art of music, train the power of hearing, and introduce various sounds to children. 4) Model, the teacher can use artificial models such as motorcycles, cars, rickshaws and others to help give a picture of the means of transportation to children.

\section{Educational Calendar}

An education calendar is a detailed schedule of activities and learning in educational institutions that are arranged to facilitate the arrangement of the agenda that has been planned for one year. Kaldik (Academic Calendar) PAUD contains an important day of children's play and learning activities for one year consisting of semesters 1 and 2 supplemented by information on national holidays during the 2019/2020 school year.

\section{Evaluation}

Curriculum assessment is conducted periodically and has been set in time. Every once a month the students' parents are invited to discuss and talk about the learning that has been done one month before. This assessment is intended so that the curriculum and learning that has been applied to be better and if there are errors can be immediately corrected. Parents of students say that learning done to achieve the development of students is in accordance with the age level of children. Their children like to play around in PAUD, then the kindergarten group has been directed to preparation for entering elementary school (SD), such as practicing early reading skills and early arithmetic. Before starting the school year, all students' parents were 
Volume 1 (3) 2020

E-ISSN: 2723-6919 P-ISSN:2746-0827

invited and given an explanation of the learning objectives in TKIT Islahul Ummah Prabumulih City. Learning in PAUD has also been adjusted to the implementation of PAUD. Parents can also understand that the intended learning is appropriate for their child's age. Even so, some parents sometimes ask why their children have not been immediately given learning to read, write and count, even though such learning is well planned in PAUD TKIT Islahul Ummah, Prabumulih City.

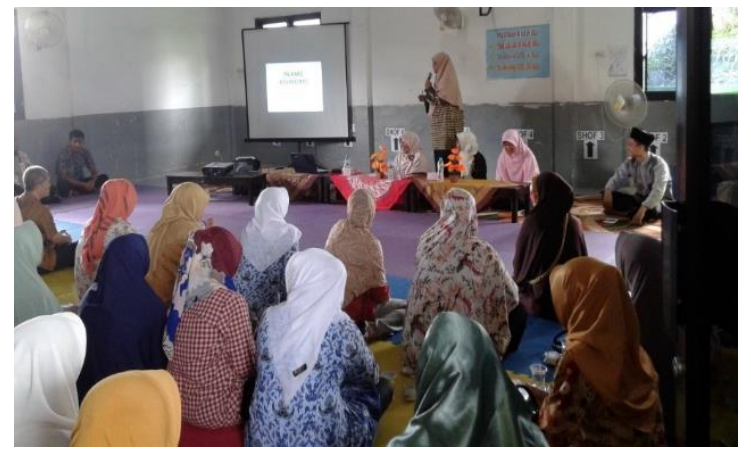

Figure 6. Monthly Meetings Discussing Evaluation of Learning

The implementation of curriculum supervision at TKIT Islahul Ummah goes through three stages. The first set of measurement tools (standards) for curriculum supervision, the second held an assessment, and the third held a correction to further improve the curriculum development for the coming year. Whereas evaluations at TKIT Islahul Ummah include educator evaluations and student evaluations.

\section{Conclusion}

The results of the analysis of the findings and discussion of research on management of early childhood education curriculum at TKIT Islahul Ummah Prabumulih City are as follows. 1) Planning curriculum management for early childhood education at TKIT Islahul Ummah, is a development planning process that is programmed and compiled by the school principal with a national curriculum and TKIT Islahul Ummah characteristic curriculum. Then from the annual planning, semester, and weekly activity plans have integrated capabilities to be achieved with other abilities, especially religious. Before planning activities, weekly meetings are held together by the teacher. This learning activity is gathered in accordance with the theme which takes place in one week. With the theme makes it easier to find activities related to student development, so that the learning plan can run effectively and efficiently. 2) Implementation of Early Childhood Education Curriculum Management at TKIT Islahul Ummah in implementing its curriculum refers to the national curriculum with additional Islamic religious material. The concept of Early Childhood Education curriculum management that is applied in the implementation of curriculum management is the learning model of a combination of classical and center. 3) Evaluation carried out in the curriculum management of TKIT Islahul Ummah, through activities carried out by students from the beginning of the activity to the end of the activity. Such as student enthusiasm for learning, direct practice and assignments, discipline and responsibility for the given task, obey the rules both in class and at school. 


\section{E. Acknowledgement}

We thank to the Rector Universitas PGRI Palembang, Universitas Bengkulu, Universitas Muhammadiyah Palembang and friends who have supported us to do this project.

\section{References}

Afiif, A., Hijriah, H., Amran, A. N. A., Sahwa, A., Awwahah, Z., \& Annisa, F. (2019). Manajemen Kurikulum Pendidikan Anak Usia Dini di TK Negeri Pembina Jeneponto [Management of Curriculum for Early Childhood Education at TK Negeri Pembina Jeneponto]. NANAEKE: Indonesian Journal of Early Childhood Education, 2(2), $92-$ 98.

Balipost.com. (2019). Ajang Kreativitas Pegiat PAUD se-Indonesia [A Creative Arena for PAUD throughout Indonesia]. Jakarta.

Bisnis.com. (2017). Presiden Jokowi Akui Pentingnya Pendidikan Usia Dini [President Jokowi Admits the Importance of Early Childhood Education]. Diakses dari: https://kabar24.bisnis.com/read/20170921/15/691756/presiden-jokowi-akuipentingnya-pendidikan-usia-dini.

Irawan, E. (2020). Manajemen Pengembangan Kurikulum (Studi di Lab Site Balai Pengembangan PAUD dan Pendidikan Masyarakat Sumatera Utara) [Curriculum Development Management (Study at the Lab Site of the Center for Early Childhood Development and Community Education in North Sumatra)]. Jurnal Manajemen Pendidikan Dasar, Menengah dan Tinggi [JMP-DMT], 1(1).

Rozalena., \& Kristiawan, M. (2017). Pengelolaan Pembelajaran PAUD dalam Mengembangkan Potensi Anak Usia Dini [PAUD Learning Management in Developing Early Childhood Potential]. JMKSP (Jurnal Manajemen, Kepemimpinan, dan Supervisi Pendidikan) Vol 2, No 1, 2017. https://jurnal.univpgripalembang.ac.id/index.php/JMKSP/article/view/1155/0

Liputan6.com. (2019). PAUD untuk Pendidikan Karakter, bukan Calistung [PAUD is for Character Education, not Calistung]. Diakses dari https://www.liputan6.com/news/read/3897418/kemendikbud-paud-untuk-pendidikankarakter-bukan-calistung.

Masitoh. (2014). Strategi Pembelajaran TK [Kindergarten Learning Strategies]. Banten: Universitas Terbuka.

Mukminin, A., \& Cahyani, M. D. (2017). Pengelolaan Pendidikan Anak Usia Dini Pemula di Kecamatan Grabag Kabupaten Purworejo [Management of Early Childhood Education for Beginners in Grabag District, Purworejo Regency]. Journal of Nonformal Education, 3(1), 47-52.

Suharni, S. (2019). Manajemen Kurikulum pada PAUD As Sakinah, Rumbai, Pekanbaru [Curriculum Management at PAUD As Sakinah, Rumbai, Pekanbaru]. PERNIK: Jurnal Pendidikan Anak Usia Dini, 1(01), 26-37. 
Journal of Social Work and Science Education

Volume 1 (3) 2020

E-ISSN: 2723-6919 P-ISSN:2746-0827

Ulfa, M., \& Munastiwi, E. (2020). Analisis Perencanaan dalam Manajemen Pendirian Lembaga Pendidikan Anak Usia Dini [Planning Analysis in the Management of the Establishment of Early Childhood Education Institutions]. LEADERIA: Jurnal Manajemen Pendidikan Islam, 1(1), 26-37. 